\title{
BioéthiqueOnline
}

\section{Pain, Disability, and Art: A Response to Verpaelst}

\section{Devan Stahl}

Volume 5, 2016

URI : https://id.erudit.org/iderudit/1044292ar

DOI : https://doi.org/10.7202/1044292ar

Aller au sommaire du numéro

Éditeur(s)

BioéthiqueOnline

ISSN

1923-2799 (numérique)

Découvrir la revue

Citer cet article

Stahl, D. (2016). Pain, Disability, and Art: A Response to Verpaelst. BioéthiqueOnline, 5. https://doi.org/10.7202/1044292ar

\section{Résumé de l'article}

La douleur est intrinsèquement subjective et modulée par la culture, il est donc difficile de la mesurer et de la soulager. La création artistique possède la capacité d'être thérapeutique aux personnes atteintes de douleur chronique.
Ce document est protégé par la loi sur le droit d'auteur. L'utilisation des services d'Érudit (y compris la reproduction) est assujettie à sa politique d'utilisation que vous pouvez consulter en ligne.

https://apropos.erudit.org/fr/usagers/politique-dutilisation/ 


\title{
Pain, Disability, and Art: A Response to Verpaelst
}

\author{
RÉPONSE À - TRAVAIL CRÉATIF / RESPONSE TO - CREATIVE WORK \\ Devan Stahl ${ }^{1}$
}

Reçu/Received: 29 Aug 2016

Publié/Published: 5 Oct 2016

Éditeurs/Editors: Aliya Affdal \& Vincent Couture

Travail créatif discuté/Creative Work discussed: F. Verpaelst. A pain in my neck BioéthiqueOnline 2015, 4/10

2016 D Stahl, $\underline{\text { Creative Commons Attribution 4.0 International License }}$

\section{Résumé}

La douleur est intrinsèquement subjective et modulée par la culture, il est donc difficile de la mesurer et de la soulager. La création artistique possède la capacité d'être thérapeutique aux personnes atteintes de douleur chronique.

\section{Mots clés}

douleur chronique, souffrance, incapacité, thérapie artistique, médecine

\section{Summary}

Pain is inherently subjective and culturally mitigated and so it is difficult to measure and mitigate. Art creation has the ability to be therapeutic to persons in chronic pain.

\section{Keywords}

chronic pain, suffering, disability, art therapy, medicine

Affiliations des auteurs / Author Affiliations

${ }^{1}$ Center for Ethics and Humanities in the Life Sciences, College of Human Medicine, East Fee Hall, USA

Correspondance / Correspondence

Devan Stahl, Devan.Stahl@hc.msu.edu

\section{Conflit d'intérêts}

Aucun déclaré
Conflicts of Interest

None declared

Preventing or mitigating suffering is commonly understood to be a moral obligation in medicine, because pain, particularly chronic, has the ability to strip persons of their dignity [1]. As a clinical ethicist, I am accustomed to encountering patients in pain that is not easily controlled. As Frank Verpaelst writes, pain has the ability to bleed the joy from our lives [2]. Yet, according to the Canadian Pain Society, up to 1 in 5 of Canadians suffer from chronic pain [3]. The medical community struggles to deal adequately with patients' pain in part because pain is inherently subjective. Anyone who has ever been asked by a clinician to rate their pain on a numerical scale or point to an increasingly grimacing face has understood that pain, unlike other disease processes or symptoms, is not easily categorized in medicine. Pain is inherently an individual, phenomenological experience, which is influenced not only by biology, but also by social expectations and individual interpretations. In The Culture of Pain, David Morris writes, "...the experience of pain is decisively shaped or modified by individual human minds and by specific human cultures." [4, p.1] Morris believes that the medical community struggles to adequately deal with the "invisible epidemic" of pain because pain must be understood from a cultural and not a disease model. Vacillating guidelines on opioids for chronic pain testify to the fact that controlling chronic pain is no easy endeavour $[5,6]$. In the medical ethics course I teach, pain relief and opioid prescription becomes not merely a medication question, but an ethical one: how do we fulfill our moral obligations to relieve pain while helping our patients avoid drug addiction?

A common narrative about the suffering disabled body often complicates the pain felt by persons with disabilities. Most contemporary disability theorists I work with identify disability as both a biological reality and a social construction. People with disabilities can suffer both from aspects of their own physical embodiment and through structures that disallow them from fully participating in society, such as architectural barriers, social stigma, and discriminatory behaviour. Disability, like pain, is a 
biological, psychological, and social experience. Unfortunately, it is all too common in contemporary culture for temporarily abled-bodied persons to assume all people with disabilities suffer as a result of their embodiment or live a painful existence. Similarly, it is all too common for the medical community to understand disability through the medical model, which defines disability with a set of identifying symptoms and then locates these symptoms in a person [7]. In response to common conceptions about the disabled body and the disability experience, persons with disabilities often hide their pain from others. Frequently, when I am attending an event or conference made up of persons with disabilities and their allies, I hear phrases like, "I wouldn't feel comfortable saying this to able-bodied people, but..." Pain, like disability, can make everyday activities difficult and admitting to pain might yet be one more reason to be excluded, as Verpaelst testifies.

Unfortunately, a disabled body in pain risks disconnecting from the world. Sociologist Arthur Frank writes "a self disassociated from its body will rarely seek to discover association with others, so the disciplined body becomes monadic [8, p.41]." Pain is inherently lonely because it cannot be shared and it can cause us to disengage from others and even from ourselves. Art is one way to work through pain, while at the same time connecting with oneself. Verpaelst is not alone in finding the act of creating art to be therapeutic. According to the American Art Therapy Association, art therapy can help people "resolve conflicts and problems, develop interpersonal skills, manage behavior, reduce stress, increase self-esteem and self-awareness and achieve insight." [9] Art therapy literature confirms Verpaelst's assertion that creating art can both distract a person from physical pain and "be a mechanism through which subconscious psychological material can be processed." [10, p.118] The use of art therapy for chronic and persistent pain is still nascent and this is likely because it does not conform to the traditional ways that medicine attempts to address ill health [9, p.128]. Moreover, art demands time, patience, and creativity, which is difficult to accommodate in a clinical setting. If in fact pain is culturally embedded and individually interpreted, however, then the act of art creation seems an ideal tool to work through chronic pain. The more we in medicine understand health as a biopsychosocial phenomenon, the more open we might be to such novel therapies and we may even encourage physicians to prescribe them.

\section{List of References}

1. Cassell E. The nature of suffering and the goals of medicine. New England Journal of Medicine. 1982;306(11):639-645.

2. Verpaelst $F$. A pain in my neck. BioéthiqueOnline, 2015;4/10.

3. The Canadian Pain Society, Pain in Canada fact sheet, 2014.

4. Morris D. The Culture of Pain. Berkeley: University of California Press; 1991.

5. Centers for Disease Control and Prevention, $\mathrm{CEC}$ guideline for prescribing opioids for chronic pain March 16, 2016

6. Canada: National Opioid Guideline Group, Canadian guideline for safe and effective use of opioids for chronic non-cancer pain, April 30, 2010.

7. Stroman DF. The Disability Rights Movement: From Deinstitutionalization to SelfDetermination. New York: University Press of America; 2003.

8. Frank AW. The Wounded Storyteller: Body, Illness, and Ethics. Chicago, IL: University of Chicago; 1995.

9. American Art Therapy Association. What is art therapy?, 2013.

10. Angheluta AM, Lee BK. Art therapy for chronic pain: applications and future directions. Canadian Journal of Counselling and Psychotherapy. 2011;45(2):112-131. 